\title{
Assessment of lumped hydrological balance models in peninsular Spain
}

Julio Pérez-Sánchez ${ }^{1}$, Javier Senent-Aparicio ${ }^{1}$, Francisco Segura-Méndez ${ }^{1}$, David Pulido-Velazquez ${ }^{1}$ ${ }^{1}$ Department of Polytechnic Science, University of Polytechnic Science, UCAM University of San Antonio of Murcia, Campus 5 los Jerónimos, $n^{\circ}$ 135, 30107 Guadalupe. Murcia (Spain)

Correspondence to: Julio Pérez-Sánchez (jperez058@ucam.edu)

\begin{abstract}
The assessment of inflows in a water resources system is essential for the appropriate analysis of its management. These inflows can be obtained from hydrological balance models. In this paper, we intend to perform a comparative study of six lumped hydrological balance models in several basins with different climatic conditions within Spain. Lumped models

10 enable the estimation of catchment resources without using spatially distributed information that would not be available in many cases. We have selected basins where long time series of climatic and hydrological data are available (more than 30 years) to calibrate parsimonious models, taking into account the stochastic behaviour of the natural streamflow and the climatic variables. The study period comprises 34 years (1977-2010). The explored models are Témez, ABCD, GR2M, the Australian water balance model (AWBM), GUO-5 parameters (Guo-5p) and Thornthwaite-Mather. Six statistical indices are applied to 15 compare the results of the models: Nash-Sutcliffe model efficiency coefficient (NSE), root-mean-square deviation (RMSE), Pearson's correlation coefficient (R), percent bias (PBIAS), RMSE-observations standard deviation ratio (RSR) and the relative error between observed and simulated runoff volumes (REV). The results show that although lumped models can be employed in humid and sub-humid regions, the more humid the catchments are, the better the results obtained. Témez models provide the worst results in dry sub-humid and semi-arid regions. Guo-5p estimates runoff volumes with errors below $10 \%$ despite the unsatisfactory results provided according to the Bressiani classification. The Bressiani classification takes into account different comparison criteria to help in the decision-making process when selecting a model. Nevertheless, the assessment of the margin of error in total runoff volume using REV is also a key index. The usefulness of Pearson's correlation when selecting a model is quite low but can be helpful in the analysis of models' weaknesses.
\end{abstract}

\section{Introduction}

25 Water resources assessment is key to the analysis of catchment management (Wurbs, 2005). The development of models to study water-management policies is a complex task that presents a fundamental scientific challenge (Welsh, 2007). Especially complex cases occur in arid and semi-arid regions, where precipitation is limited and/or irregular and evapotranspiration (ET) rates are high. Hydrological balance models are used to reconstruct historical series and predict future ones (Puricelli, 2003). They are based on the principle of mass conservation or the continuity equation (Essam, 2007; Rose, 2004), which considers that the difference of inputs and outputs will be reflected in water storage in the catchment (Shimon, 2010; UNESCO, 1981). 
Hydrol. Earth Syst. Sci. Discuss., https://doi.org/10.5194/hess-2017-424

Manuscript under review for journal Hydrol. Earth Syst. Sci.

Discussion started: 11 August 2017

(c) Author(s) 2017. CC BY 4.0 License.

The concept of hydrological balance models was first introduced by Thornthwaite (1948) and Thornthwaite and Mather (1957). They proposed two different conceptual models based on two parameters: soil moisture capacity and water excess above the maximum soil moisture storage capacity. These models demonstrated a good fit to estimate monthly runoff (Alley, 1984) and have formed the basis of many other two-parameter hydrological models (Xiong and Guo, 1999; Makhlouf and Michel, 1994;

5 Giakoumakis et al., 1991; Mimikou et al., 1991; Alley, 1985, 1984). There are also water balance models that comprise more than two parameters (Abulohom et al., 2001; Yates and Strzepek, 1998; Vandewiele et al., 1992). However, Xiong and Guo (1999) showed that their proposed two-parameter model in China performed as well as a five-parameter model. To date, several studies have shown that many models produce similar results to previous ones (Andreassian et al., 2006; Perrin et al., 2001; Chiew et al., 1993; World Meteorological Organization, 1975). In a lumped water balance model, catchment parameters and 10 variables are averaged in space, so hydrological processes are approached by conceptual solutions formulated by using semiempirical equations. The system is described using different reservoirs, the moisture content of which depends on the relationships (physical and empirical) between them (Xu and Singh, 1998). A lumped hydrological balance model may have only three or four parameters (Xu and Singh, 1998; Vandewiele et al., 1992; Alley, 1984) and can be implemented with several lines of computer code, whereas a complex model may have more than 20 parameters (Chiew, 2010). Some examples of 15 lumped models are the ABCD model (Zhao et al., 2016; Wang and Tang, 2014; Sankarasubramanian and Vogel, 2002; Alley, 1985) GR2M (Lacombe et al., 2016; Mouelhi et al., 2006), Sacramento (Burnash et al., 1973), Guo-5p (Xiong and Guo, 1999; Guo, 1995), Témez (Singh and Kumar, 2016; Singh, 2000; Ferrer, 1993; Témez, 1991, 1987), Thornwaite-Mather (Lyon et al., 2004; Frankenberger et al., 1999; Calvo, 1986), IHACRES (Croke et al., 2006), SIMHYD (Chiew et al., 2002), GR4J (Perrin et al., 2003), AWBM (Boughton, 2009, 2007, 2006, 2004; Boughton and Chiew, 2007) and SMAR (O'Connel et al., 1970). More examples of rainfall-runoff models can be found in Singh (1995) and Singh and Frevert (2002).

With the new development of computer aided tools and more detailed information, there is an increasing trend to use distributed or semi-distributed models (Eder et al., 2005; Arnold et al., 1998). They provide more detailed distributed results on a catchment scale approximating heterogeneities of the system. However, uncertainty at high resolution may diminish potential gains in prediction accuracy (Carpenter, 2006). Nevertheless, despite the simplicity of lumped models, they perform well in many studies (Yang and Michel, 2000; Cameron et al., 1999; Uhlenbrook et al., 1999; Yang et al., 1995). However, they do not need as much data as the distributed models (which are unavailable in many cases), and the complexity and requirements to process them are lower. Furthermore, calibration of the lumped parameter models is much less time consuming and produced higher overall model performance in comparison to the more complex distributed models (Vansteenkiste et al., 2014). They are particularly useful in small data-rich catchments and are used in conjunction with field studies (Chiew, 2010). Various studies have been conducted to compare distributed and lumped models (Koren et al., 2004; Zhang et al., 2004; Boyle et al., 2001; Refsgaard and Knudsen, 1996; Shah et al., 1996). The suitability of a model depends on the basin and specific regional characteristics. 
The aim of this study is to analyse and compare six lumped water balance models in 16 basins located in different climatic regions of Spain. We have selected basins where long time series of climatic and natural streamflow data are available (more than 30 years). We intend to calibrate parsimonious models by considering the stochastic behaviour of the natural streamflow and climatic variables. The aim is to select the models with the best fit and assess the comparison methods used according to

5 the characteristics of the region. The contents of the paper are structured as follows: the data and study area are introduced in Section 2; methodology is described in Section 3; Section 4 presents the results and discussion and Section 5 highlights the main conclusions.

\section{Study area and data}

Spain is the second largest country in Western Europe, with a territory covering 505,990 km², a dense network of rivers with

10 many branches and a large number of aquifers. This disparity within the Iberian Peninsula is optimal for hydrological research. Spain features a wide range of climates due to its position between the European temperate zone and the subtropical zone. It also includes some of the rainiest areas in Europe in the northeast and the driest areas in the southeast, with a marked summer drought. To ensure the validity of the results, the 16 selected catchments are in natural regime. They are located all over the country, as shown in Figs. 1 and 2. Thus, geographic and climatic variety in Spain is reflected wherever data were available.

15 Their altitudes vary from 1,632 to 342 metres above sea level (MASL), and catchment areas range from $29 \mathrm{~km}^{2}$ to $837 \mathrm{~km}^{2}$ with an average of $300 \mathrm{~km}^{2}$ (Table 1). There is no south-western catchment in this study due to the lack of data in this area, where most gauging stations have data for a period of less than 10 years. As shown in Table 1, the average temperatures range from $8-16^{\circ} \mathrm{C}$, depending on the latitude and average altitude of the catchment, with a positive gradient to the south. With regard to the rainfall regime, the highest yearly precipitation occurs in the north of Spain, where average temperatures are

20 lower and, consequently, ET is less. However, in the southern half of the Iberian Peninsula, ET is generally higher than precipitation, especially in the lowlands, which have an average altitude of less than 600 metres.

The study area comprises the most common climate groups in the Iberian peninsula, according to Köppen's $(1936,1918,1884)$ classification: Bsk., Csb., Csa., Cbf. and UNEP aridity index (UNEP, 1997). This index (AIU) is defined by Eq. 1.

$$
A I_{U}=\frac{P}{P E T}
$$

where $\mathrm{P}$ is the average annual precipitation and PET is the potential ET. The thresholds that define the various degrees of aridity depend on the value of AIU according to Table 2 .

Among the 16 catchments studied, nine are considered humid; thus, their AIU exceeds one, and five of them even have an aridity index near to or above two. All are located in northern Spain. Despite the rainfall gradient from Northwest to Southeast, the SEG and ZUM catchments are classified as humid sub-humid due to their altitude above 1,000 MASL. The BOL catchment,

30 which is close to the Mediterranean Sea, is the only eastern dry sub-humid region of the regions studied; thus, the other dry sub-humid catchments (TAM and CUE) are located in the centre of the Iberian Peninsula. The only semi-arid region in the studied catchments is RVA, the average altitude of which is approximately 600 MASL. 
Precipitation and ET data series in each basin are from a 33-year period (1977-2010). They were obtained from the official monthly series provided by the CEDEX (Centre of Studies and Experimentation of Civil Works) for the Spanish government (Álvarez et al., 2005) at a spatial resolution of 500x500 $\mathrm{m}^{2}$ (Estrela and Quintas, 1996). The model has been validated at more than 100 control points (Estrela et al., 1999) and used in Spain for water resources assessment, in the White Paper Book of

5 Waters (Ministry of Environment 2000) and the National Water Master Plan (Ministry of Environment 2002), and in several studies (Pérez-Martín et al., 2014; González-Zeas et al., 2012; Belmar et al., 2011). Natural streamflow data in each catchment are available for the same period. They come from measurements at gauging stations in the official Spanish network. The range of missing values moves from $2 \%$ to $8 \%$ in the stations considered.

\section{Methodology}

10 The methods used in this investigation are based on the identification of the hydrological models that best fit each catchment considered. Six monthly water balance models were used: Témez, ABCD, GR2M-1994, Australian Water Balance Model (AVBM), Guo-5p and Thornwaite-Mather. All these models use precipitation and potential ET as input data. Finally, the assessment of the goodness of fit for the six models was mainly performed using the ratings Moriasi et al. (2007) suggested, and the grading system proposed by Bressiani et al. (2015). We also analysed the Pearson's correlation coefficient and the

15 relative error between observed and simulated runoff volumes in the studied period. All of these hydrological models are defined with four parameters, except Thornwaite-Mather (three parameters) and Guo-5p. (five parameters). The models conduct different moisture balances according to the different processes in a hydrological system through all phases of the hydrological cycle. The processes are governed by the continuity principle and mass balance and remain regulated by the specific laws of division and transfer between the balance parameters (Cabezas et al., 1999).

\section{$20 \quad 3.1$ Water balance models}

\subsubsection{Témez model}

Témez (1977) developed the Témez model, which has been widely used in Spanish catchments (Escriva-Bou et al., 2017, MIMAM, 2000; Cabezas et al., 1999; Estrela et al., 1999) and by the Spanish government in water management (Estrela, 1992). This model considers the system to be divided into two (Fig. 3): the upper or non-saturated zone (S) and the lower or saturated zone $(\mathrm{G})$. Some of the precipitation $(\mathrm{P})$ drains directly into the river or through the aquifer, while the remainder is converted into ET. Excess is divided into runoff (Qs) through river networks at the present time, and infiltration to aquifers, draining one part $(\mathrm{Qg})$ at the present time, with the rest remaining in the groundwater storage tank $(\mathrm{G})$ for draining at a later date. 
Hydrol. Earth Syst. Sci. Discuss., https://doi.org/10.5194/hess-2017-424

Manuscript under review for journal Hydrol. Earth Syst. Sci.

Discussion started: 11 August 2017

(c) Author(s) 2017. CC BY 4.0 License.

\subsubsection{ABCD Model.}

The ABCD 4-parameter model (Alley, 1984) introduces a different formulation in ET process and allows for a water surplus even though the soil moisture tank (S) is not full yet. As shown in Fig. 3, this model also considers two storage tanks: upper storage (S) or soil and groundwater storage (G). The upper storage tank (S) has two outputs: runoff (Qs) and infiltration. Thus,

5 the model has two inputs, precipitation (P) and ET, and their outputs are soil moisture content at the end of the month (S), monthly available water, real ET, runoff $(\mathrm{Qs})$, infiltration, groundwater runoff $(\mathrm{Qb})$, monthly groundwater storage $(\mathrm{G})$ and total runoff (Q) (Fig. 3).

\subsubsection{GR2M-1994 Model (GR4-1994).}

This model (Makhlouf and Michel, 1994) was developed in the 1990s by the CEMAGREF (Centre of Agricultural and

10 Environmental Research of France). It is also based on monthly precipitation and ET (Edijatno and Michel, 1989). Afterwards, the model evolved into different versions, such as GR1A, GR2M, GR3J and GR4J, denominated the number of required parameters and the last letter denominating the period considered: J (daily), M (monthly) or A (yearly). GR2M transforms precipitation into runoff through the implementation of two equations: production and transfer functions (Kabouya, 1990; Edijatno and Michel, 1989). Initially, P and ET are balanced and precipitation is distributed between the upper storage tank

15 (S) with a limited capacity and groundwater storage tank (G) (Paturel et al., 1995). Nief et al. (2003) showed that model parameters are robust to non-stationary rainfall series, and calibrated parameter values are highly correlated with land use. Like previous models, monthly precipitation and evapotransporation are the inputs, and the operating diagram is shown in Fig. 3.

\subsubsection{AWBM Model.}

20 The AWBM was also developed in the 1990s and is the most commonly used water balance method in Australia (Boughton, 2004). This model has three surface water-storage tanks (S1, S2 and S3). The water balance of each is estimated independently, resulting in three surpluses. One part of these surpluses is transformed into runoff $(\mathrm{Qs})$, and the other part percolates to a groundwater storage tank or aquifer $(\mathrm{G})$, which in turn goes to groundwater runoff $(\mathrm{Qg})$. Total flow $(\mathrm{Q})$ is obtained by adding both runoffs (Fig. 3).

25 3.1.5. Guo Model (five parameters).

This model was developed to estimate the runoff in 70 catchments in southern China. It has a similar performance to the twoparameter Guo model, and its use is particularly recommended in humid and semi-humid regions (Xiong and Guo, 1999; Guo, 1995). Precipitation and evapotranspiration (P and ET) are the input data, on the basis of which the remaining parameters are estimated: real ET, soil water storage (S), water surpluses, surface runoff $(\mathrm{Qs})$, subsurface runoff $(\mathrm{Qb})$, aquifer recharge, groundwater storage $(\mathrm{G})$, groundwater runoff $(\mathrm{Qg})$ and total flow $(\mathrm{Q})$. 
Hydrol. Earth Syst. Sci. Discuss., https://doi.org/10.5194/hess-2017-424

Manuscript under review for journal Hydrol. Earth Syst. Sci.

Discussion started: 11 August 2017

(c) Author(s) 2017. CC BY 4.0 License.

\subsubsection{Thornthwaite-Mather Model.}

This model was developed by Thornwaite and Mather (Thornthwaite et al., 1957, 1955) in the early 1940s for the Delaware

River, and many water balance models are based on it. The model distinguishes two water storage tanks: surface (S) and groundwater $(\mathrm{G})$, which lead to the output flow $(\mathrm{Q})$ through different calculations.

\section{3.2. Goodness-of-fit tests}

The study period is 34 years (1977-2010). We employed three years for warming up, and the other 30 years, starting October 1980, for calibration and validation, applying the split sample test proposed by KlemeŠ (1986). Therefore, the data series from 1980 to 2010 (30 years) was divided into two sets. The first 15 years (1980-1995) were used for calibration, and the remaining 15 years (1995-2010) were used in model verification, namely as a security measure of calibration. Thus, model parameters

10 that best fit the simulated data versus the observed data are obtained. The gradient reduced algorithm (GRG2) (Ríos, 1988; Abadie, 1978; Lasdon and Waren, 1978; Lasdon et al., 1978) was used to calibrate the parameters. Once the model was calibrated and the parameters validated, the predictive stage was executed.

To evaluate model accuracy, six statistic indices were obtained: NSE (Nash and Sutcliffe, 1970), RMSE (Hyndman et al., 2006), R (Pearson, 1895), PBIAS (Gupta et al., 1999), RSR (Moriasi et al., 2007) and REV (Karpouzos et al., 2011). The

15 formulas used are presented in Table 3, with optimal values as recommended by Moriasi et al. (2007).

According to Moriasi et al. (2007) and Bressiani et al. (2015), a grading method was established to evaluate the good performance of the model based on the NSE, RSR and PBIAS values. A model was considered unsatisfactory if one of the previous tests is set as unsatisfactory according to Moriasi et al. (2007). In any other case, the grading system proposed by Bressiani et al. (2015) was applied to classify the models in four categories: very good, good, satisfactory and unsatisfactory 20 (Table 4).

\section{Results and discussion}

For a better understanding of the research and subsequent discussion, the results are ranked in tables and figures according to the AIU values. After assessing the six water balance models for the 16 catchments, described in the previous section, we calculated R of the observed and simulated streamflows (Qobs-Qsim) for all evaluated approaches (Table 5). GR2M shows the best fit in most catchments (13 out of 16), both semi-arid and sub-humid, with an average correlation coefficient of close to 0.90 . Only the HOY catchment has a correlation coefficient below 0.80 (0.67). Furthermore, the ABCD and AWBM models did not give the best fit for any of the studied catchments, though their values were similar to those using GR2M, especially for humid and sub-humid catchments. All water balance models show correlation coefficients above 0.80 for humid and humid sub-humid catchments. In the dry sub-humid HOY catchment, some values fell below 0.60, especially with the Témez and 30 Thornthwaite-Mather models and RVA. The Témez model, which is widely used in Spain, achieves the best fit only in the 
Hydrol. Earth Syst. Sci. Discuss., https://doi.org/10.5194/hess-2017-424

GAR catchment, taking the same value (0.92) as Guo-5p, and similar to the GR2M coefficient $(0.90)$. The more arid the catchment, the lower the average correlation coefficient obtained.

Fig. 4 shows the scatter plot for each catchment obtained using the best model in terms of correlation coefficient. Dispersion is generally greater for the largest streamflows, while the remaining simulated flows appear to have similar order of magnitude.

5 The perfect fit line (solid line), which indicates that simulated streamflows are identical to observed streamflows, is usually above the estimated regression line (dashed line). Nevertheless, in RVA, flow estimates are below real estimates, and peak flows are more irregularly distributed than the rest of the study catchments, which is characteristic of these latitudes.

The average NSE for each model considering the 16 basins (Fig. 5, upper left) shows good results for all models except Témez, for which the NSE (0.44) is below 0.50 . Despite being a five-parameter model, Guo-5p would be only satisfactory according

10 to the NSE criterion; thus, its value (0.54) is below 0.65 . The rest of the models achieve around 0.65 and could be considered good. In contrast, PBIAS (Fig. 5, upper right) shows better results than the Guo-5p and Témez models, the values of which are $0.65 \%$ and $4.35 \%$, respectively. Nevertheless, the rest of the models always give below $15 \%$ and could be considered good. The Thornthwaite-Mather model is the only "good" model according to RSR criterion (at the bottom left of Fig. 5) and all the others are satisfactory, with the exception of the Témez model (unsatisfactory because its average value is below 0.70 ).

15 According to the Bressiani criteria (Fig. 5, bottom right), only the Témez model is unsatisfactory, whereas the rest are, on average, between good and satisfactory.

With regard to the average of the models' results in each basin (Fig. 6), the influence of the aridity index is highlighted. In all basins, from the HOY catchment to the driest catchment, the NSE values (Fig. 6, upper left) are considered unsatisfactory on average, taking into account all the models studied. This same occurs in relation to RSR (Fig. 6 bottom left), with values below

200.70 in the HOY catchment and drier ones. Due to the better results obtained for the PBIAS (Fig. 6, upper right) in all catchments except for the TAM catchment, the Bressiani criteria show unsatisfactory results in the four basins that are drier than the JUB catchment and in the HOY catchment (Fig. 6, bottom right).

Table 6 summarizes the classification sum according to the Bressiani criteria for all studied catchments and models. GR2M gives the best fit for nearly $40 \%$ of the catchments with values over 7 , meaning they all have a very good fit. ABCD model

25 has very similar results in five of the 16 catchments studied. The Témez and Thornthwaite-Mather models are the best in four and three catchments, respectively. However, the value obtained with the Temez model in the BOL catchment is just 4. AWBM model is the best only in one catchment but shows high values (above 7) in some humid and sub-humid regions. The models that show the best results, on average, in all catchments are ABCD, GR2M and Thornthwaite-Mather, with values around 4.5. AWBM and Témez show the worst results, with 3.65 and 3.00, respectively, which is almost unsatisfactory. Moreover, the Témez model shows the highest coefficient of variation (129.22\%), far from the rest of the models, the average value of which is around $80 \%$. As with previous comparison methods, the best results are obtained in more humid basins, and the drier region shows more unsatisfactory results.

If an ensemble of models is performed (Table 6), the results again depend on the aridity of the region. Humid and sub-humid ensemble models catchments could be classified as very good and good except for the PUE and COT catchments. However, 
Hydrol. Earth Syst. Sci. Discuss., https://doi.org/10.5194/hess-2017-424

the results of the dry sub-humid are more irregular, especially in the less arid regions, with classifications from good to unsatisfactory, as in the HOY catchment. The more arid regions (from BOL to RVA) did not show satisfactory results in an ensemble average model.

The main aim of hydrological balance models is to assess inflows in a water resources system, and it is essential for appropriate

5 analysis of its management. Therefore, in addition to the assessment performed with the Bressiani classification (Table 6), we should analyse the differences between total observed and simulated runoff volumes to validate or discard a model.

Table 7 shows the REV results of these comparisons for the catchments studied and the models considered. According to this criterion, Guo-5p shows the best results, on average, giving the best fitted model in six of the catchments studied. Furthermore, the Guo-5p model is the only water balance model that gives REV values below $15 \%$ in semi-arid and dry sub-humid regions,

10 despite the unsatisfactory results obtained in accordance with the Bressiani criteria (Table 6). The other models give an average REV above $50 \%$ in these catchments. With regard to humid and sub-humid catchments, the lowest REV values accord with the Bressiani classification in most cases, which allows for selecting the best model in each catchment (Table 8).

Table 8 shows the proposed model for each catchment, taking into account the proposed set of criteria: R, the Bressiani classification and REV. R does not differ greatly between the various regions, altitudes or areas, although there is a slight

15 descending trend (from 0.91 to 0.80 ) when we move to less humid catchments. HOY is the only dry sub-humid catchment where the correlation coefficient was less than 0.60 , besides obtaining a sum of only 5 in Bressiani criteria, which is far from an average of 7.5 of its aridity group. This may be because, despite being a small basin $\left(66.15 \mathrm{~km}^{2}\right)$, it is the highest catchment of those studied. Nonetheless, the Thornthwaite-Mather model is classified as good in this catchment, and REV is below $2 \%$. GR2M, The Témez and Guo-5p models are considered the models that best fit in humid regions, though in these regions,

20 almost all models show good results, with higher percentages in the GR2M model. Thornthwaite-Mather gives the best results in humid sub-humid regions, and Témez gives the worst fit, giving a classification of 'unsatisfactory' in all catchments. However, despite the 'very good' classification, REV percentages in the less humid catchments (ZUM and JUB) are around $20 \%$. The driest and semi-arid catchments did not have 'satisfactory' classifications with any of the studied models, but REV is lower than $10 \%$ when the Guo-5p model is used. In contrast, the Témez model 'satisfactory' classification in the BOL

25 catchment has an overestimate of nearly $30 \%$. No trend was found with catchment area or altitude and the models used.

Fig. 7 shows the comparison between the observed and simulated streamflows in both the calibration (1980-1995) and validation (1995-2010) periods with the selected models in the catchments studied. A qualitative inspection of the graphs shows that the simulated hydrographs are in close agreement with the observed ones. The humid and sub-humid models show good performance in predicted runoff volumes. The validation period is even better fitted than the calibration period in most catchments. Only the highest peaks in runoff discharges in humid and sub-humid regions are underestimated. Sub-humid regions follow a similar pattern, but peaks are overestimated in most catchments (SEG, ZUM, BOL and CUE). The 'unsatisfactory' classification (Table 8) in the driest basins (CUE and RVA) has different graphical results, as seen in Fig. 7. Whereas Guo-5p has a good fit in the CUE catchment for both high and low streamflows, despite an overestimation of $13.61 \%$ 
in total runoff volumes, in RVA, peaks are well estimated; however, the water model underestimates runoff volumes in the rest of the study period.

\section{Summary and conclusions}

Spain has a wide climatic variety due to its complex orography and geographic situation. It has the driest and rainiest regions

5 in continental Europe. Indeed, the 16 basins selected as case studies cover a range of aridity index classifications from humid to semi-arid. Lumped hydrological balance models were proved to perform well in humid and sub-humid regions, regardless of the catchments' altitude or area, showing good results in all cases according to the Bressiani rank classification. The driest regions register 'unsatisfactory' performance for the lumped models used, although the estimated runoff volumes with Guo$5 \mathrm{p}$ are very similar to the observed ones with differences below $10 \%$, which is even lower than in some dry sub-humid regions.

10 GR2M is the model that generally gives the best fit in Spain, although other models provide slightly better results when a detailed analysis is performed. The more humid the catchment is, the better any water model fits. In the driest regions, it is the opposite. However, despite the poor results according to the Bressiani classification, the Guo-5p model showed low REV, which indicates that it could be used as a good estimator in water management. The Thornthwaite-Mather model fits the best in dry sub-humid regions. The Témez model, widely used in Spain, only performed well in humid regions, as many of the 15 other water balance models did, but it had the worst results in the dry sub-humid region. It only gave the best fit in the BOL catchment, but its REV was nearly $+30 \%$, significantly overestimating water resources in the basin, which could consequently lead to inadequate water management.

The usefulness of R when selecting a model is quite low but can be helpful in the analysis of models' weaknesses regarding highest and lowest runoff volumes and extraordinary situations. The Bressiani classification takes into account different

20 comparison criteria (NSE, RSR and PBIAS) to help in the decision-making process when selecting a model. Nevertheless, the assessment of the margin of error in total runoff volume by using REV is also a key index. NSE and RSR leads to ordering and identifying the models that fit better, but PBIAS does not show conclusive results and can even distort the Bressiani classification. The REV criterion assesses both the overestimation and underestimation of the total, which is a key factor in the analysis of water-management problems. The methodology used can be applied in regions with similar case studies to assess more accurately the resources within a system.

Competing interests. The authors declare that they have no conflict of interest.

Acknowledgments. The authors gratefully acknowledge support from the UCAM University of San Antonio of Murcia through the project "PMAFI/06/14". This research was also partially supported by the GESINHIMPADAPT project (CGL2013-48424C2-2-R) with Spanish MINECO funds. 
Hydrol. Earth Syst. Sci. Discuss., https://doi.org/10.5194/hess-2017-424

Manuscript under review for journal Hydrol. Earth Syst. Sci.

Discussion started: 11 August 2017

(c) Author(s) 2017. CC BY 4.0 License.

\section{References}

Abadie, J. The GRG Method for Nonlinear Programming, Greenberg, H.J.(Ed), Design and Implementation of Optimization Software, Sijthoff and Noordhoof, pp. 325-363, 1978.

Abulohom, M.S., Shah, S.M.S, Ghumman A.R. Development of a rainfall-runoff model, its calibration and validation. Water

5 Resour. Manag., 15,149-163, 2001.

Alley, W. M. Water balance models in one-month-ahead streamflow forecasting. Water Resour. Res., 21, 4, 597-606, doi:10.1029/ WR021i004p00597, 1985.

Alley, W.M. On the treatment of evapotranspiration, soil moisture accounting, and aquifer recharge in monthly water balance models. Water Resour. Res, 20, 1,137-1,149, 1984.

10 Andréassian, V., Hall, A., Chahinian, N., Schaake, J. Introduction and Synthesis: Why should hydrologists work on a large number of basin data sets? IAHS Publication No. 307, Large sample basin experiments for hydrological model parameterization: Results of the Model Parameter Experiment - MOPEX, Paris, 1-5, 2006.

Arnold, J. G., Srinivasan, R., Muttiah, R. S., Williams, J. R. Large-area hydrologic modeling and assessment: Part I. Model development. J. American Water Resour. Assoc., 34, 1, 73-89, 1998.

15 Boughton, W. New approach to calibration of the AWBM for use on ungauged catchments. J. Hydrol. Eng., 14,6, 562-568, doi: 10.1061/(ASCE)HE.1943-5584.0000025, 2009.

Boughton, W. Effect of data length on rainfall-runoff modelling. Environ. Model. Softw., 22, 3, 406-413, doi: 10.1016/j. envsoft.2006.01.001, 2007.

Boughton, W., Chiew, F. Estimating runoff in ungauged catchments from rainfall, PET and the AWBM model. Environ. Model. Softw., 22, 4, 476-487, doi: 10.1016/j.envsoft.2006.01.009, 2007.

Boughton, W. Calibrations of a daily rainfall-runoff model with poor quality data. Environ. Model. Softw., 21, 8, 1114-1128, doi: 10.1016/j.envsoft.2005.05.011, 2006.

Boughton, W. The Australian Water Balance Model. Environ. Model. Softw, 19,10, 943-956, doi: 10.1016/j. envsoft.2003.10.007, 2004.

25 Boyle, D. P., Gupta, H. V., Sorooshian, S., Koren, V., Zhang, Z., Smith, M. Toward improved streamflow forecasts: Value of semidistributed modeling. Water Resour. Res., 37, 11, 2749 - 2759, 2001.

Bressiani D.A., Srinivasan, R., Jones, C.A., Mendiondo, E.M. Effects of spatial and temporal weather data resolutions on streamflow modeling of a semi-arid basin, Northeast Brazil. Int. J. Agric. \& Biol. Eng., 8, 3, 125-139, 2015.

Burnash, R.J.C., Ferral, R.L., Maguire, R.A. A Generalized Streamflow Simulation System: Conceptual Models for Digital

30 Computers, Joint Federal State River Forecast Center, Sacramento, CA, 1973.

Cabezas, F., Estrada, F., Estrela, T. Algunas contribuciones técnicas del Libro Blanco del Agua en España. Ingeniería Civil, $115,79-96,1999$. 
Hydrol. Earth Syst. Sci. Discuss., https://doi.org/10.5194/hess-2017-424

Manuscript under review for journal Hydrol. Earth Syst. Sci.

Discussion started: 11 August 2017

Calvin, R. An Introduction to the Environmental Physics of Soil, Water and Watersheds. University of Cambridge, United Kingdom, 2004.

Calvo, J.C. (1986) An evaluation of Thornthwaite's water balance technique in predicting stream runoff in Costa Rica. Hydrolog. Sci. J., 31, 1, 51-60, doi: 10.1080/02626668609491027, 1986.

5 Cameron, D.S., Beven, K.J., Tawn, J., Blazkova, S., Naden, P. Flood frequency estimation by continuous simulation for a gauged upland catchment (with uncertainty). J. Hydrol., 219, 169-187, 1999.

Carpenter, T. M. Discretization scale dependencies of the ensemble flow range versus catchment area relationship in distributed hydrologic modeling. J. Hydrol., 328, 1-2, 242-257, doi:10.1016/j.jhydrol.2005.12.008, 2006.

Chiew, F.H.S. Lumped conceptual rainfall-runoff models and simple water balance methods: Overview and applications in 10 ungauged and data limited regions. Geogr. Compass., 4, 3, 206-225, 2010.

Chiew, F.H.S., Kirono, D.G.C., Kent, D.M., Frost, A.J., Charles, S.P., Timbal, B., Nguyen, K.C., Fu, G., Comparison of runoff modelled using rainfall from different downscaling methods for historical and future climates. J. Hydrol., 387, 1-2, 10-23, 2010.

Chiew, F.H.S., McMahon, T.A. Modelling the impacts of climate change on Australian streamflow. Hydrol. Process., 16, $15 \quad 1235-1245,2002$.

Chiew, F.H.S., McMahon T.A. Australian data for rainfall-runoff modelling and the calibration of models against streamflow data recorded over different time periods. Civil Engineering Transactions. The Institution of Engineers, Australia, CE35 (3), 261-274, 1993.

Croke, B. F. W., Andrews, F., Jakeman, A. J., Cuddy, S. M., Luddy, A. IHACRES classic plus: A redesign of the IHACRES 20 rainfall-runoff model. Environ. Modell. Softw., 21, 3, 426-427, doi: 10.1016/j.envsoft.2005.07.003, 2006.

Eder, G., Fuchs, M., Nachtnebel, H., Loibl, W. Semi-distributed modelling of the monthly water balance in an alpine catchment. Hydrol. Process., 19, 2339-2360, 2005.

Edijatno, Michel, C. Un modèle pluie-débit journalier a trois paramètres. LHB1., 2, 113-121, 1989.

Essam, M. Water Flow and Chemical Transport in a Subsurface Drained Watershed. University of Illinois, United States of 25 América, 2007.

Estrela, T., Cabezas, F., Estrada, F. La evaluación de los recursos hídricos en el libro blanco del agua en España. Ingeniería del Agua 1999, 6, 2, 125-138, 1999.

Estrela, T., Quintas, L. A distributed hydrological model for water resources assessment in large basins. Rivertech '96 -1st International Conference on New/Emerging Concepts for Rivers, Proceedings, Vol. 1-2, 861-868, 1996.

30 Estrela, T. Modelos matemáticos para la evaluación de recursos hídricos. Centro de Estudios Hidrográficos y Experimentación de Obras Públicas, CEDEX, 1992.

Ferrer, J. Recomendaciones para el cálculo hidrometeorológico de avenidas. CEDEX M-37, CEDEX: Madrid, Spain, 1993. Frankenberger, J.R., Brooks, E.S., Walter, M.T., Walter, M.F., Steenhuis, T.S. A GIS-Based Variable Source Area Hydrology Model. Hydrol. Process., 13, 6, 804-822, 1999. 
Hydrol. Earth Syst. Sci. Discuss., https://doi.org/10.5194/hess-2017-424

Giakoumakis, S., Tsakiris, G., Efremides, D. On the rainfall-runoff modelling in a Mediterranean island environment. Advances in Water Resources Technology, G. Tsakiris (ed.), Balkema, Rotterdam, pp. 137-148, 1991.

Guo, S. Impact of climate change on hydrological balance and water resource systems in the Dongjiang Basin, China. Modeling and Management of Sustainable Basin-Scale Water Resource Systems (Proceedings of a Boulder Symposium, LAHS Publ.

$5231,1995$.

Gupta, H.V., Sorooshian, S., Yapo, P.O. Status of automatic calibration for hydrologic models: Comparison with multilevel expert calibration. J. Hydrologic Eng., 4, 2, 135-143, 1999.

Hyndman, R., Koehler J. Koehler, A.B. Another look at measures of forecast accuracy. Int. J. Forecast.,.22, 4, 679-688, doi:10.1016/j.ijforecast.2006.03.001, 2006.

10 Kabouya, M. Modélisation pluie-débit aux pas de temps mensuel et annuel en Algérie septentrionale. Thèse de Doctorat Thesis, Université Paris Sud Orsay, 1990.

Pearson, K. Notes on regression and inheritance in the case of two parents. Proc. R. Soc. Lond., 58, 240-242, 1985.

Karpouzos, D.K., Baltas, E.A., Kavalieratou, S., Babajimopoulos, C. A hydrological investigation using a lumped water balance model: the Aison River Basin case (Greece). Water Environ. J., 25, 3, 297-307, doi:10.1111/j.1747-

15 6593.2010.00222.x, 2011.

Singh, K., Kumar, A. Evaluation of relief aspects morphometric parameters derived from different sources of DEMs and its effects over time of concentration of runoff (TC). Earth Sci. Inform., doi: 10.1007/s12145-016-0261-7, 2016.

KlemeŠ, V. Operational testing of hydrological simulation models. Hydrol. Sci. J., 31, 13-24, 1986.

Köppen, W. "C". In Köppen, Wladimir, Geiger, Rudolf. Das geographische System der Klimate, Handbuch der Klimatologie,

20 1. Berlin: Borntraeger, 1936.

Köppen, W. Klassification der Klimate nach Temperatur, Niederschlag and Jahreslauf. Petermanns Geographische Mitteilungen. pp. 193-203, 243-248,1918.

Köppen, W. Die Wärmezonen der Erde, nach der Dauer der heissen, gemässigten und kalten Zeit und nach der Wirkung der Wärme auf die organische Welt betrachtet. Meteorologische Zeitschrift, 20, 3, 351-360, 1884 ..

25 Koren, V., Reed, S., Smith, M., Zhang, Z., Seo, D.J. Hydrology laboratory research modeling system (HL-RMS) of the US national weather service. J. Hydrol., 291, 297-318, 2004.

Lacombe, G., Ribolzi, O., De Rouw, A., Pierret, A., Latsachak, K., Silvera, N., Dinh, R.P., Orange, D., Janeau, J.L., Soulileuth, B., Robain, H., Taccoen, A., Sengphaathith, P., Mouche, E., Sengtaheuanghoung, O., Duc, T.T., Valentin, C. Contradictory hydrological impacts of afforestation in the humid tropics evidenced by long-term field monitoring and simulation modelling.

Hydrol. Earth Syst. Sci., 20, 7, 2691-2704, 2016

Lasdon, L.S., Waren, A.D. Generalized Reduced Gradient Software for Linearly and Nonlinearly Constrained Problems. Greenberg, H.J.(Ed), Design and Implementation of Optimization Software, Sijthoff and Noordhoof, pp. 363-397, 1978.

Lasdon, L.S., Waren, A.D., Jain, A., Ratner, M. Design and Testing of a Generalized Reduced Gradient Code for Nonlinear Constrained Programming. ACM Trans.Math. Softw., 4, 34-50, 1978. 
Hydrol. Earth Syst. Sci. Discuss., https://doi.org/10.5194/hess-2017-424

Manuscript under review for journal Hydrol. Earth Syst. Sci.

Discussion started: 11 August 2017

Lyon, S.W., Walter, M.T., Gerard-Marchant, P., Steenhuis, T.S. Using a topographic index to distribute variable source area runoff predicted with the SCS curve-number equation. Hydrol. Proc., 18, 2757-2771, 2004.

Makhlouf, Z., Michel, C. A two-parameter monthly water balance model for French watersheds. J. Hydrol., 162, 299-318, 1994.

5 MIMAM. Libro Blanco del Agua en España. Centro de Publicaciones del Ministerio de Medio Ambiente. Madrid, 2000.

Mimikou, M.A., Hadjisawa, P.S., Kouvopoulos, Y.S., Afrateos, H. Regional climate change impacts: II. Impacts on water management works. Hydrol, Sci. J., 36, 3, 259-270, 1991.

Moriasi, D.N., Arnold, J.G., Van Liew, M.W., Bingner, R.L., Harmel, R.D., Veith, T.L. Model evaluation guidelines for systematic quantification of accuracy in watershed simulations. Trans. ASABE, 50, 3, 885-900, 2007.

10 Mouelhi, S., Michel, C., Perrin, C., Andréassian, V. Stepwise development of a two-parameter monthly water balance model. J. Hydrol., 318, 200-214, 2006.

Nash, J.E., Sutcliffe, J.V. River flow forecasting through conceptual models: Part 1. A discussion of principles. J. Hydrol., 10, 3, 282-290, 1970.

Nief, H., Paturel, J.E., Servat, E. Study of parameter stability of a lumped hydrologic model in a context of climatic variability.

15 J. Hydrol., 278, 213-230, 2003.

O’Connell, P.E., Nash, J.E., Farrell, J.P. River flow forecasting through conceptual models, Part 2, The Brosna catchment at Ferbane. J. Hydrol., 10, 4, 317-329, 1970.

Paturel, J.E., Servat, E., Vassiliadis, A. Sensitivity of conceptual rainfall-runoff algorithms to errors in input data. Case of the GR2M model. J. Hydrol., 168, 111-125, 1995.

20 Perrin, C., Michel, C., Andréassian, V. Improvement of a parsimonious model for streamflow simulation. J. Hydrol., 279, 14, 275-289, 2003.

Perrin C., Michel, C., Andreassian, V. Does a large number of parameters enhance model performance? Comparative assessment of common catchment model structures on 429 catchments. J. Hydrol., 242, 3-4, 275-301, 2001.

Puricelli, M. M. Estimación y distribución de parámetros del suelo para la modelación hidrológica. Universidad Politécnica

25 de Valencia, Departamento de Ingeniería Hidráulica y Medio Ambiente. Tesis Doctoral, 2003.

Ríos, S. Investigación operativa. Centro de Estudios Ramón Areces. Madrid, 1988.

Sankarasubramanian, A., Vogel, R.M. Annual hydroclimatology of the United States. Water Resour. Res., 38, 6, 1083, doi:10.1029/ 2001WR000619, 2002.

Shah, S. M. S., O'Connell, P. E., Hosking, J. R. M. Modelling the effects of spatial variability in rainfall on catchment response.

30 2. Experiments with distributed and lumped models. J. Hydrol., 175, 1, 89-111, 1996.

Shimon, C. Water Resources. Island Press, United States of America, 2010.

Singh, V.P., Frevert, D.K. Mathematical Models of Small Watershed Hydrology and Applications. Water Resources Publications, Littleton, Colorado, USA, 2002.

Singh, S.K. Transmuting synthetic unit hydrograph into gamma distribution. J. Hydrol. Eng., 5, 380-385, 2000. 
Hydrol. Earth Syst. Sci. Discuss., https://doi.org/10.5194/hess-2017-424

Manuscript under review for journal Hydrol. Earth Syst. Sci.

Discussion started: 11 August 2017

Singh, V. P. Watershed modeling. ed., Computer Models of Watershed Hydrology (1st Edition), pp. 1-22. Highlands Ranch, Colorado: Water Resources Publications, 1995.

Témez, J.R. Extended and Improved Rational Method: Version of the Highways Administration of Spain. In Proceedings of XXIV Congress of IAHR, Madrid, Spain, September 1991, Volume A, pp. 33-40, 1991.

5 Témez, J.R. Cálculo hidrometeorológico de caudales máximos en pequeñas cuencas naturales. Dirección General de Carreteras, MOPU, Madrid, Spain, 1987.

Témez, J.R. Modelo Matemático de trasformación "precipitación-escorrentía". Asociación de Investigación Industrial Eléctrica. ASINEL. Madrid, 1977.

Thornthwaite, C.W., Mather, J.R. Instructions and Tables for Computing Potential Evapotranspiration and the Water Balance.

10 Climatology, 10, 3, 1957.

Thornthwaite, C.W., Mather, J.R. The water balance. Publ. Climatol., 8, 1, 1955.

Thornthwaite, C.W. A new and improved classification of climates. Geogr. Rev., 38, 1, 55-94, 1948.

Uhlenbrock, S., Seibert, J., Leibundgut, C., Rohde, A. Prediction uncertainty of conceptual rainfall-runoff models caused by problems in identifying model parameters and structure. Hydrol. Sci. J., 44, 779-797, 1999.

15 Unesco. Methods for Water Balance Computation. Instituto de Hidrología de España. España, 1981.

UNEP (United Nations Environment Programme). World atlas of desertification. 2ED. UNEP, London, 1997.

Vandewiele, G. L., Xu, C.Y., Win, N.L. Methodology and comparative study of monthly water balance models in Belgium, China and Burma. J. Hydrol., 134, 315-347, doi:10.1016/0022-1694(92) 90041-S, 1992.

Vansteenkiste, T., Tavakoli, M., Ntegeka, V., De Smedt, F., Batelaan, O., Pereira, F., Willems, P. Intercomparison of 20 hydrological model structures and calibration approaches in climate scenario impact projections. J. Hydrol., 519, 743-755, 2014.

Wang, D., Tang, Y. A one-parameter Budyko model for water balance captures emergent behavior in Darwinian hydrologic models. Geophys. Res. Lett., 41, 4569-4577, doi:10.1002/2014GL060509, 2014.

Welsh, W.D. Groundwater balance modelling with Darcy's law. PhD thesis. 2007.

25 World Meteorological Organization. Intercomparison of Conceptual models used in operational forecasting (Operational Hydrology Report no. 7, WMO-No. 429), WMO, Geneva, Switzerland, 1975.

Wurbs, R.A. Texas water availability modeling system. J. Water Resour. Plan. Manage., 131, 4, 270-279, 2005.

Xiong, L., Guo, S. A two-parameter monthly water balance model and its application. J. Hydrol., 216, 111-123, 1999.

Xu, C.Y., Singh, V.P. Dependence of evaporation on meteorological variables at different time-scales and intercomparison of estimation methods. Hydrol. Process., 12, 429-442, 1998.

Yang, X., Michel, C.. Flood forecasting with a watershed model: a new method of parameter updating. Hydrolog. Sci. J., 45, 537-546, 2000.

Yang, X., Parent, E., Michel, C., Roche, P.A. Comparison of real-time reservoir operation techniques. J. Water Resour. Plann. Manage., 121, 5, 345-351, 1995. 
Hydrol. Earth Syst. Sci. Discuss., https://doi.org/10.5194/hess-2017-424

Manuscript under review for journal Hydrol. Earth Syst. Sci.

Discussion started: 11 August 2017

Yates, D., Strzepek, K. Modeling the Nile basin under climate change. J. Hydrol. Eng., 3, 2, 98-108, 1998.

Zhang, Z., Koren, V., Smith, M., Reed, S., Wang, D. Use of next generation weather radar data and basin disaggregation to improve continuous hydrograph simulations. J. Hydrol. Eng., 9, 2, 103-115, 2004.

Zhao, J., Wang, D., Yang, H., Sivapalan, M. Unifying catchment water balance models for different time scales through the

5 maximum entropy production principle. Water Resour. Res., 52, doi:10.1002/2016WR018977, 2016.

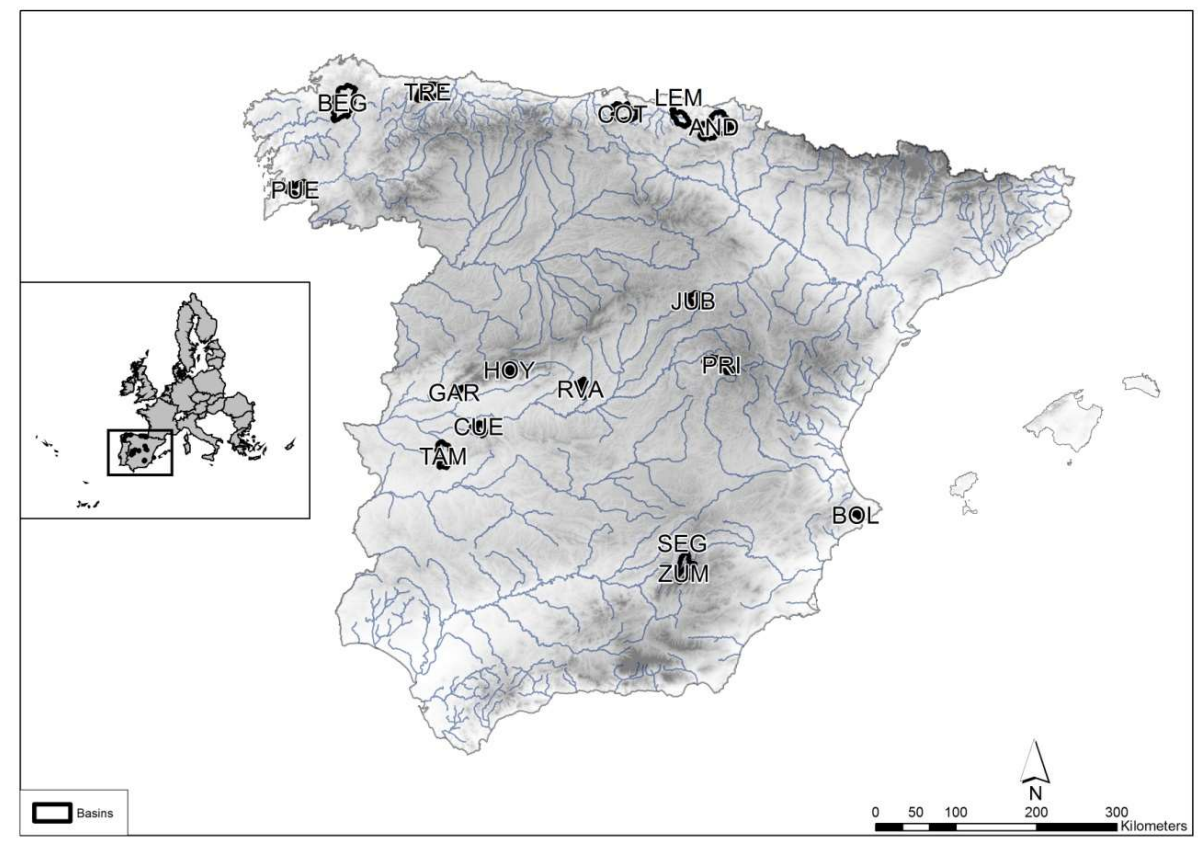

Fig. 1. Position and location of catchments. 
Hydrol. Earth Syst. Sci. Discuss., https://doi.org/10.5194/hess-2017-424

Manuscript under review for journal Hydrol. Earth Syst. Sci.

Discussion started: 11 August 2017
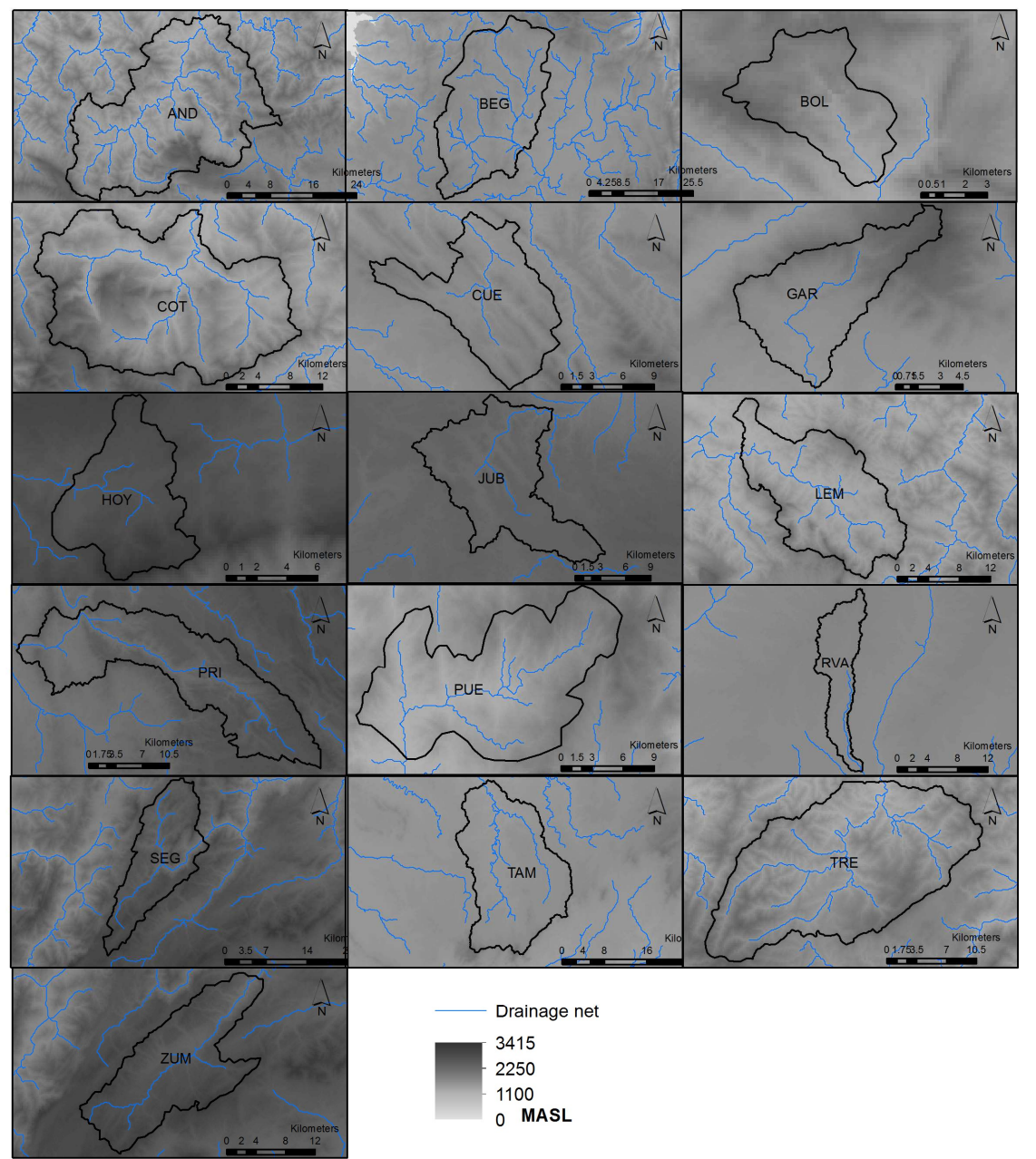

Fig. 2. Morphology, drainage net and elevation of test catchments. 
Hydrol. Earth Syst. Sci. Discuss., https://doi.org/10.5194/hess-2017-424

Manuscript under review for journal Hydrol. Earth Syst. Sci.

Discussion started: 11 August 2017

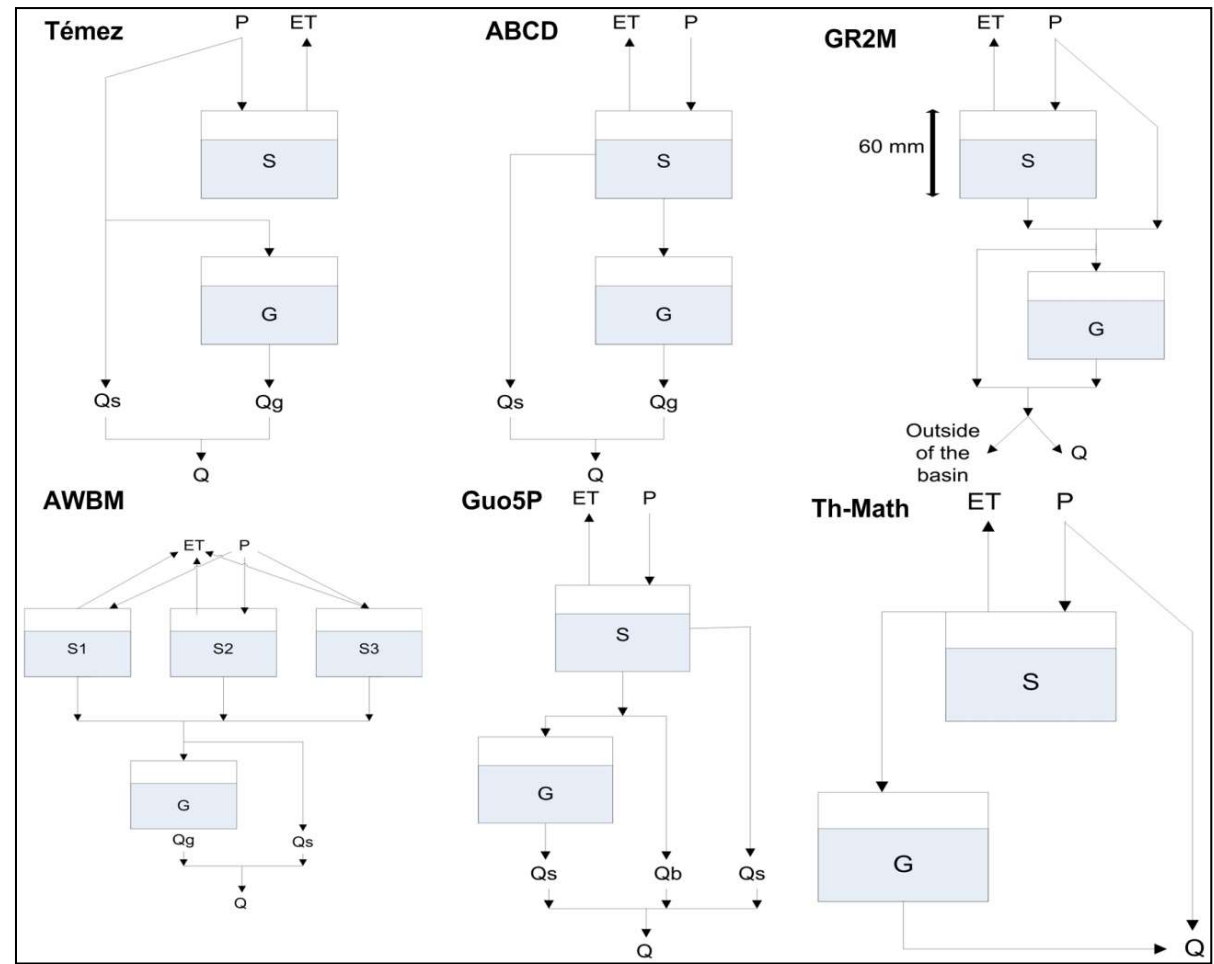

Fig. 3. Conceptual representation of the six water balance models studied. 
Hydrol. Earth Syst. Sci. Discuss., https://doi.org/10.5194/hess-2017-424

Manuscript under review for journal Hydrol. Earth Syst. Sci.

Discussion started: 11 August 2017

(c) Author(s) 2017. CC BY 4.0 License.
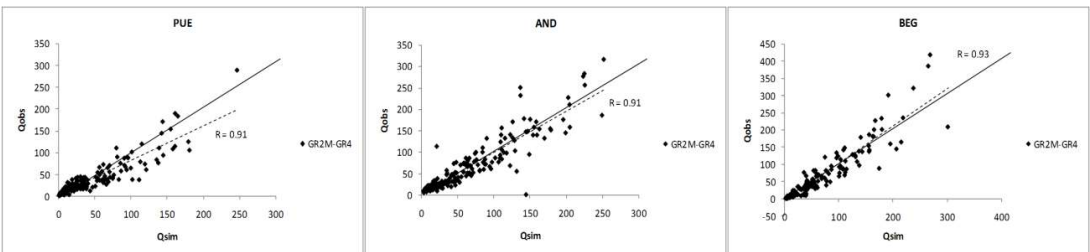

10

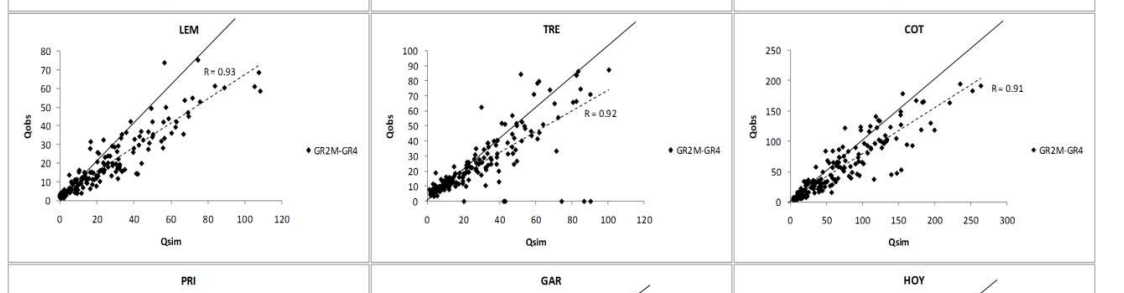

15

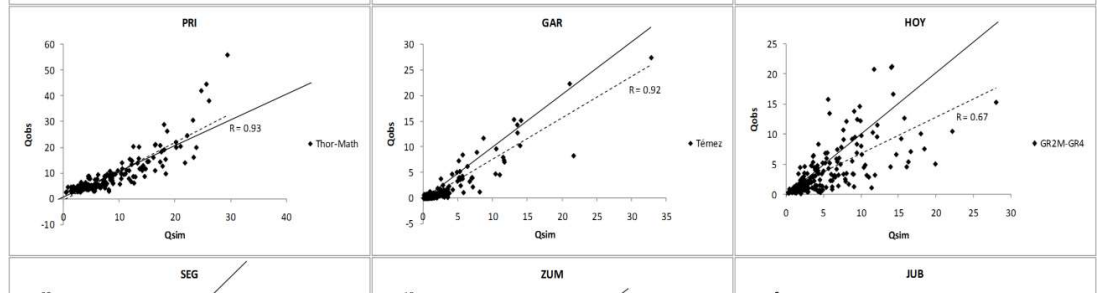

20
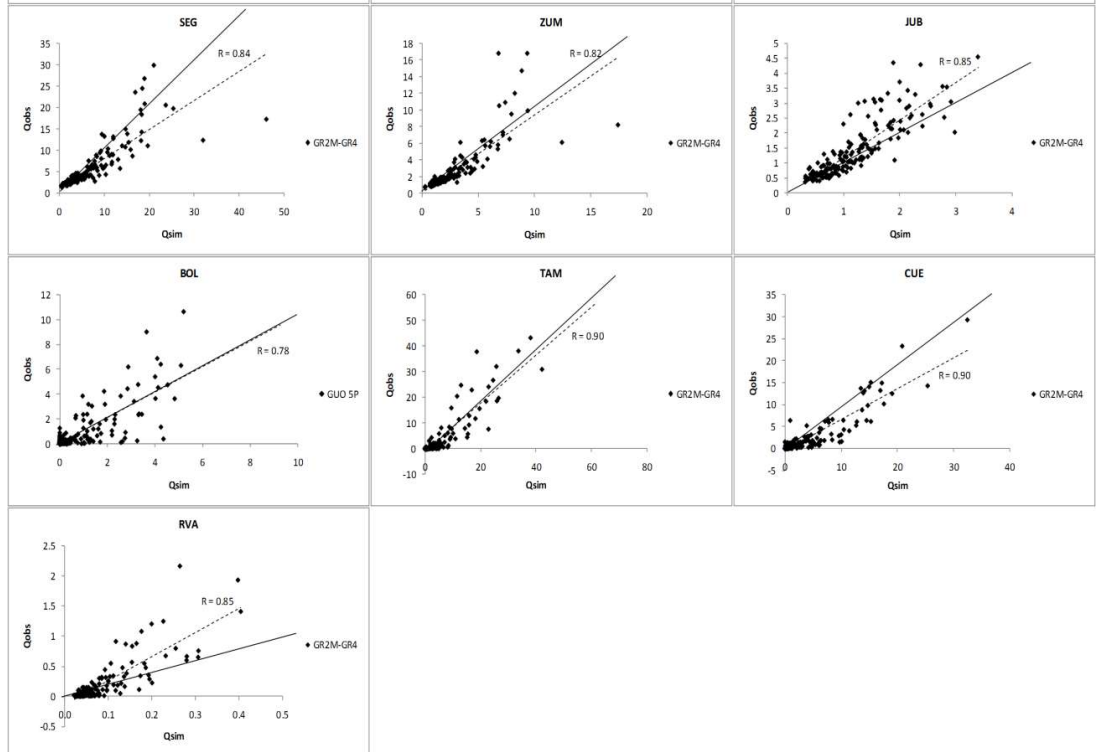

Fig. 4. Scatter plots (observed and simulated streamflows in hm3/month) for best model fit according to Pearson's correlation coefficient $(R)$. The dashed line is the estimated regression line, and the solid line is the perfect fit. 
Hydrol. Earth Syst. Sci. Discuss., https://doi.org/10.5194/hess-2017-424

Manuscript under review for journal Hydrol. Earth Syst. Sci.

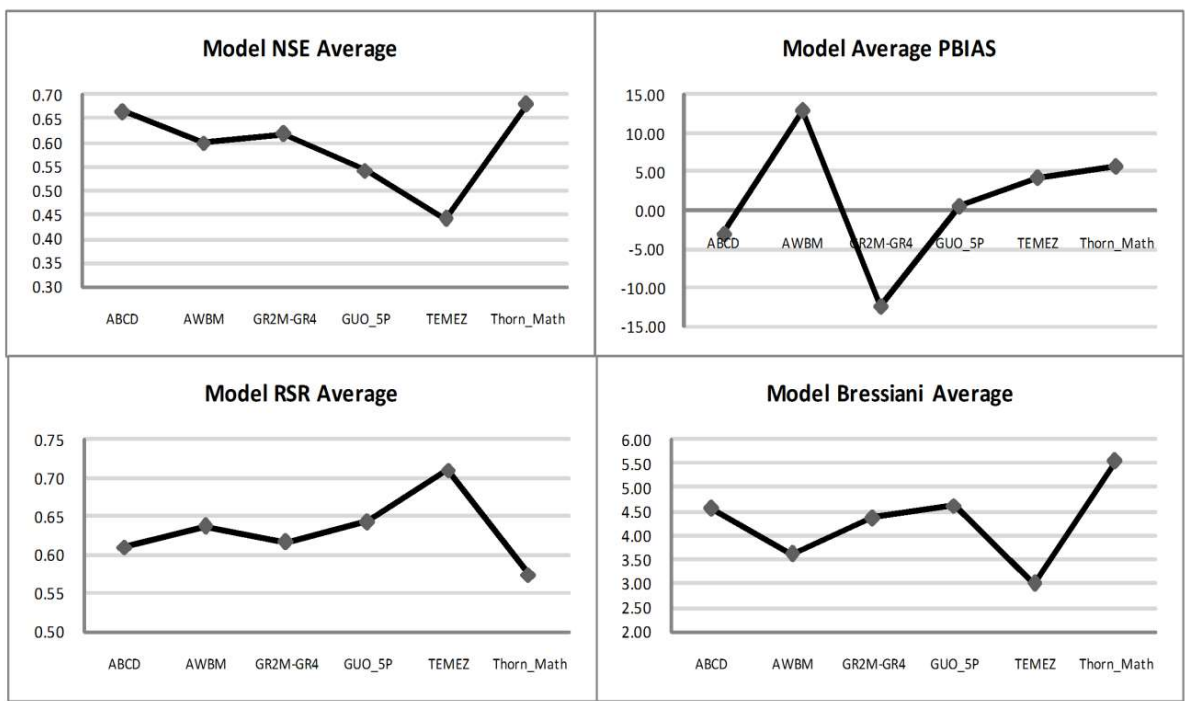

Fig. 5. Model average comparison

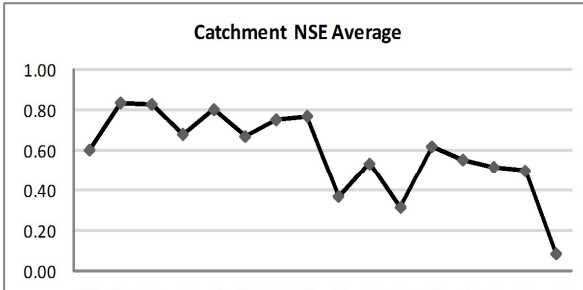

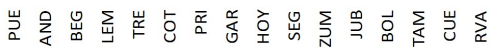
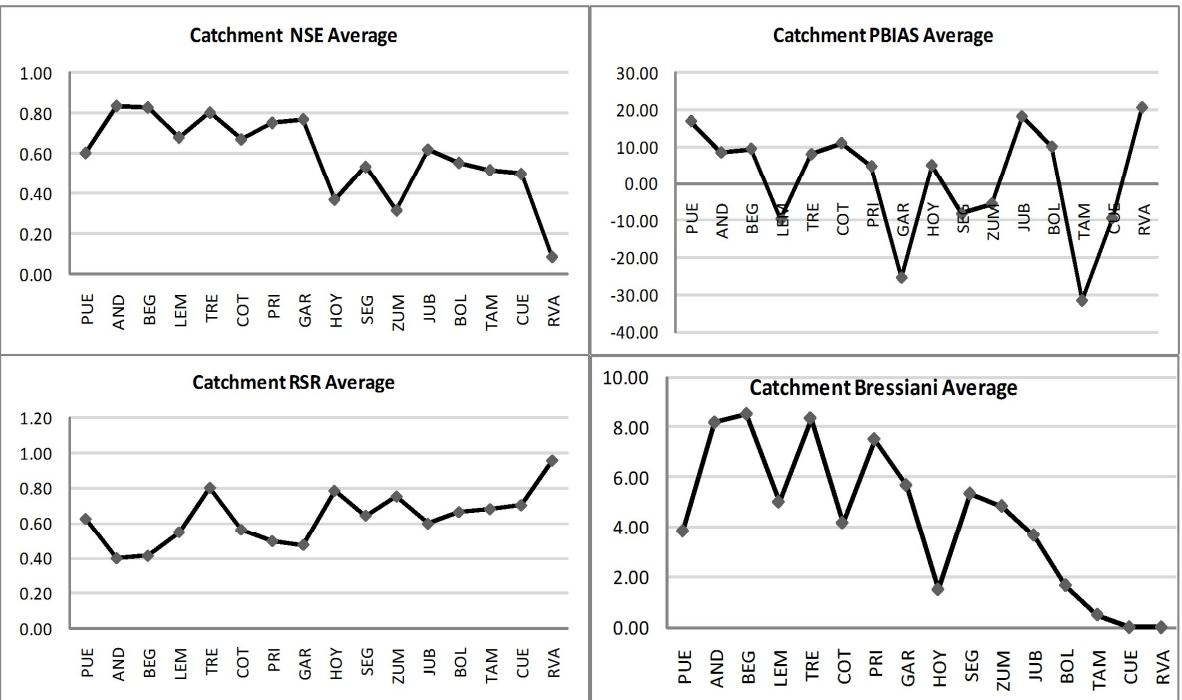

Fig. 6. Comparison of catchment averages 
Hydrol. Earth Syst. Sci. Discuss., https://doi.org/10.5194/hess-2017-424

Hydrology and Manuscript under review for journal Hydrol. Earth Syst. Sci.

Discussion started: 11 August 2017

10

15

20

25
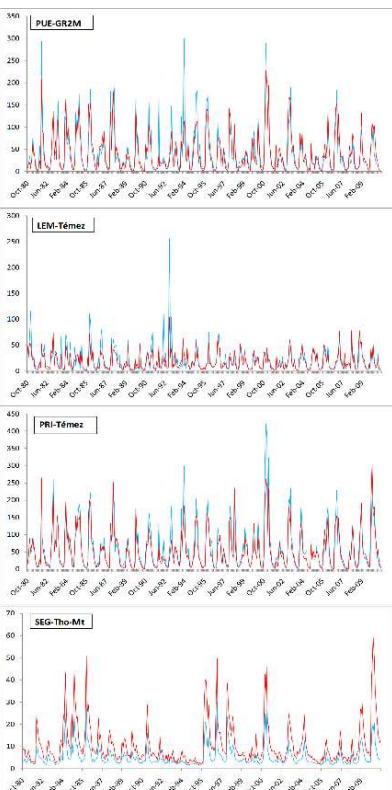

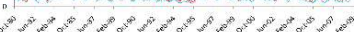

12 sou-timant

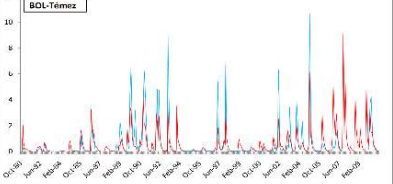

ara cusas

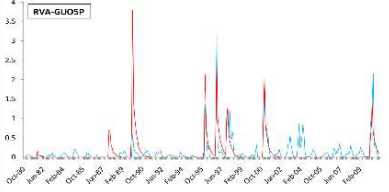

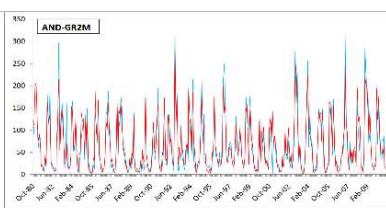

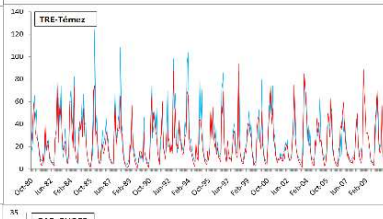

" CAR:CLOSES
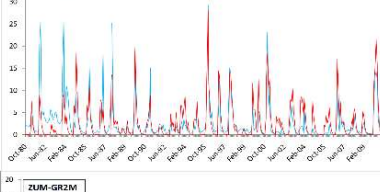

${ }^{2}$ |TAM-GJOSP

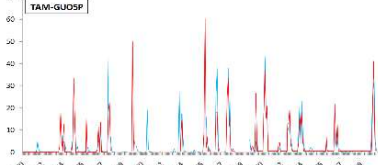

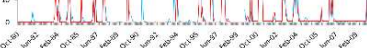

- aobs

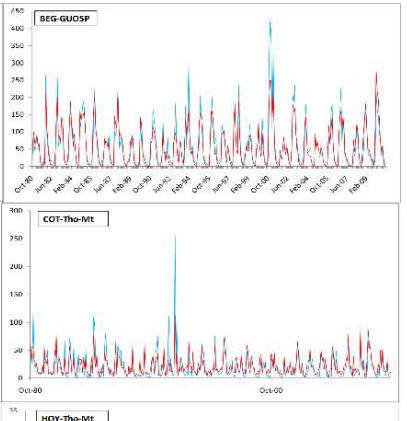

Hor-hoome

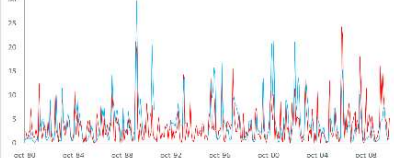

sits

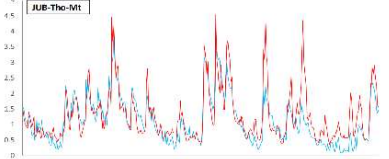

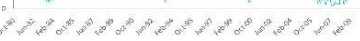

15. CUE-GUOSP

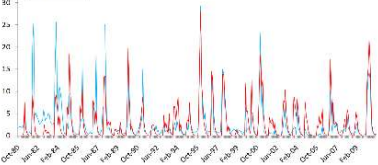

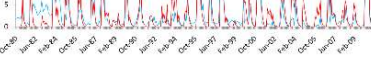

Fig. 7. Observed and simulated runoff discharge graphs in the study period (1980-2010). 
Hydrol. Earth Syst. Sci. Discuss., https://doi.org/10.5194/hess-2017-424

Manuscript under review for journal Hydrol. Earth Syst. Sci.

Discussion started: 11 August 2017

Table 1. Summary of catchments characteristics (1977-2010) (X and Y coordinates refer to the centroid of the basin.

\begin{tabular}{|c|c|c|c|c|c|c|c|c|c|}
\hline Code & $\begin{array}{l}\text { Area } \\
\left(\mathbf{k m}^{2}\right)\end{array}$ & $\begin{array}{r}\text { X ETRS89 } \\
\text { UTM 30N }\end{array}$ & $\begin{array}{c}\text { Y ETRS } 89 \\
\text { UTM 30N }\end{array}$ & $\begin{array}{c}\text { MASL } \\
\text { (m) }\end{array}$ & $\begin{array}{c}\text { Köppen } \\
\text { Class. }\end{array}$ & $\begin{array}{c}\text { UNEP } \\
\text { Aridity } \\
\text { Index }\end{array}$ & $\begin{array}{c}\text { Average } \\
\text { temperature } \\
\left({ }^{\circ} \mathrm{C}\right)\end{array}$ & $\begin{array}{c}\text { Average } \\
\text { yearly } \\
\text { precipitation } \\
\text { (mm) }\end{array}$ & $\begin{array}{r}\text { Average } \\
\text { yearly } \\
\text { ETP } \\
(\mathbf{m m})\end{array}$ \\
\hline AND & 778.49 & 573531.02 & 4769234.41 & 486.01 & $\mathrm{Cfb}$ & 2.15 & 11.62 & 1563.47 & 727.86 \\
\hline BEG & 836.89 & 111096.28 & 4799111.26 & 504.01 & Csb & 2.07 & 11.44 & 1332.62 & 632.50 \\
\hline $\mathrm{BOL}$ & 29.23 & 749970.13 & 4286756.78 & 600.31 & Csa & 0.54 & 16.56 & 579.71 & 1080.30 \\
\hline COT & 488.22 & 460081.35 & 4786345.03 & 559.51 & $\mathrm{Cfb}$ & 1.65 & 11.48 & 1311.12 & 793.16 \\
\hline CUE & 139.86 & 280997.89 & 4392588.21 & 610.63 & Csa & 0.52 & 15.33 & 570.56 & 1098.46 \\
\hline GAR & 69.92 & 251972.85 & 4439204.60 & 689.98 & Csa & 1.02 & 14.73 & 1060.18 & 1043.32 \\
\hline HOY & 66.15 & 318316.11 & 4466995.19 & 1632.12 & $\mathrm{Csb}$ & 1.01 & 8.58 & 777.22 & 770.35 \\
\hline JUB & 207.66 & 549719.20 & 4553001.74 & 1150.05 & $\mathrm{Csb}$ & 0.65 & 10.84 & 509.76 & 783.22 \\
\hline LEM & 252.58 & 530214.27 & 4779163.90 & 342.18 & $\mathrm{Cfb}$ & 1.96 & 12.35 & 1393.18 & 709.20 \\
\hline PRI & 328.16 & 578643.32 & 4473678.12 & 1255.05 & Csb & 1.19 & 10.96 & 763.04 & 642.86 \\
\hline PUE & 263.85 & 52975.07 & 4692077.36 & 400.05 & Csb & 2.20 & 14.07 & 1662.05 & 756.42 \\
\hline RVA & 85.68 & 407367.20 & 4444846.50 & 607.70 & Bsk & 0.40 & 14.69 & 396.53 & 998.49 \\
\hline SEG & 232.89 & 533459.57 & 4225568.22 & 1416.46 & Csb & 0.88 & 11.53 & 807.66 & 915.83 \\
\hline TAM & 458.12 & 237068.72 & 4360580.97 & 447.46 & Csa & 0.54 & 15.93 & 596.36 & 1112.84 \\
\hline TRE & 413.54 & 217492.08 & 4812225.19 & 526.64 & $\mathrm{Cfb}$ & 1.84 & 12.31 & 1220.91 & 663.77 \\
\hline ZUM & 266.03 & 536758.71 & 4213732.23 & 1549.95 & Csb & 0.79 & 11.35 & 750.28 & 951.88 \\
\hline
\end{tabular}

Table 2. Classification of the regions according to UNEP aridity index (AIU).

\begin{tabular}{cc}
\hline Classification & UNEP Aridity Index (AIU) \\
\hline Hyper-arid & $\mathrm{AI}_{\mathrm{U}}<0.05$ \\
\hline Arid & $0.05<\mathrm{AI}_{\mathrm{U}}<0.20$ \\
\hline Semi-arid & $0.20<\mathrm{AI}_{\mathrm{U}}<0.50$ \\
\hline Dry sub-humid & $0.50<\mathrm{AI}_{\mathrm{U}}<0.65$ \\
\hline Humid sub-humid & $1.00<\mathrm{AI}_{\mathrm{U}}<0.65$ \\
\hline Humid & $\mathrm{AI}_{\mathrm{U}}>1.00$ \\
\hline
\end{tabular}


Hydrol. Earth Syst. Sci. Discuss., https://doi.org/10.5194/hess-2017-424

Manuscript under review for journal Hydrol. Earth Syst. Sci.

Discussion started: 11 August 2017

Table 3. Goodness-of-fit formula tests. Qobs, Vobs and Qsim, Qsim are the observed and simulated streamflow and runoff volumes, respectively, and STDEV is the standard deviation.

\begin{tabular}{|c|c|c|c|}
\hline Goodness-of-fit test & Eq. & $\begin{array}{l}\text { Value } \\
\text { Range } \\
\end{array}$ & $\begin{array}{c}\text { Optimal } \\
\text { Value }\end{array}$ \\
\hline $\mathrm{NSE}=1-\frac{\sum_{\mathrm{i}=1}^{\mathrm{n}}\left(\mathbf{Q}_{\mathrm{obs}, \mathrm{i}}-\mathbf{Q}_{\mathrm{sim}, \mathrm{i}}\right)^{2}}{\sum_{\mathrm{i}=1}^{\mathrm{n}}\left(\mathbf{Q}_{\mathrm{obs}, \mathrm{i}}-\overline{\mathbf{Q}_{\mathrm{obs}}}\right)^{2}}$ & (2) & $-\infty$ to 1 & $>0.50$ \\
\hline$R M S E=\sqrt{\frac{\sum_{\mathrm{i}=1}^{\mathrm{n}}\left(\mathbf{Q}_{\text {sim }, \mathrm{i}}-\mathbf{Q}_{\mathrm{obs}, \mathrm{i}}\right)^{2}}{n}}$ & (3) & 0 to $\infty$ & $<\mathrm{STDEV} / 2$ \\
\hline 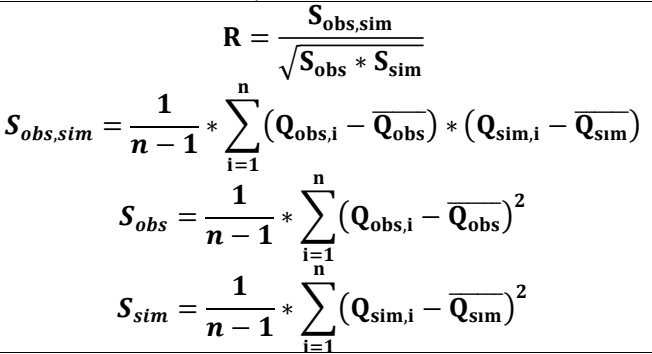 & $\begin{array}{l}\text { (4) } \\
(5) \\
\text { (6) } \\
\text { (7) }\end{array}$ & -1 to +1 & -1 or +1 \\
\hline$P B I A S=\frac{\sum_{\mathrm{i}=1}^{\mathrm{n}}\left(\mathbf{Q}_{\mathrm{obs}, \mathrm{i}}-\mathbf{Q}_{\text {sim }, \mathrm{i}}\right) * \mathbf{1 0 0}}{\sum_{\mathrm{i}=\mathbf{1}}^{\mathrm{n}} \mathbf{Q}_{\mathrm{obs}, \mathrm{i}}}$ & (8) & $\pm 100 \%$ & $\pm 25 \%$ \\
\hline$R S R=\frac{R M S E}{\operatorname{STDEV}_{\mathrm{obs}}}=\frac{\sqrt{\sum_{\mathrm{i}=1}^{\mathrm{n}}\left(\mathbf{Q}_{\mathrm{obs}, \mathrm{i}}-\mathbf{Q}_{\mathrm{sim}, \mathrm{i}}\right)^{2}}}{\sqrt{\sum_{\mathrm{i}=1}^{\mathrm{n}}\left(\mathbf{Q}_{\mathrm{obs}, \mathrm{i}}-\overline{\mathbf{Q}_{\mathrm{obs}}}\right)^{2}}}$ & (9) & 0 to $\infty$ & $\leq 0.70$ \\
\hline$R E V=\frac{\sum_{\mathrm{i}=1}^{\mathrm{n}}\left(\mathbf{V}_{\mathrm{obs}, \mathrm{i}}-\mathbf{V}_{\text {sim }, \mathrm{i}}\right)}{\sum_{\mathrm{i}=1}^{\mathrm{n}} \mathbf{V}_{\mathrm{obs}, \mathrm{i}}}$ & (10) & $\pm 100 \%$ & $\pm 25 \%$ \\
\hline
\end{tabular}

5

Table 4. Classification criteria for hydrological models (Moriasi et al., 2007; Bressiani et al., 2015).

\begin{tabular}{cccccc}
\hline & NSE & PBIAS (\%) & RSR & Grading & Classification-Sum \\
\hline Very Good (V) & $0.75<\mathrm{NSE} \leq 1.00$ & PBIAS $< \pm 10$ & $0.00 \leq \mathrm{RSR} \leq 0.50$ & 3 & $7<\mathrm{E} \leq 9$ \\
\hline Good (G) & $0.65<\mathrm{NSE} \leq 0.75$ & $\pm 10 \leq \mathrm{PBIAS}< \pm 15$ & $0.50<\mathrm{RSR} \leq 0.60$ & 2 & $5<\mathrm{E} \leq 7$ \\
\hline Satisfactory (S) & $0.50<\mathrm{NSE} \leq 0.65$ & $\pm 15 \leq \mathrm{PBIAS}< \pm 25$ & $0.60<\mathrm{RSR} \leq 0.70$ & 1 & $3<\mathrm{E} \leq 4$ \\
\hline Unsatisfactory (U) & $\mathrm{NSE} \leq 0.50$ & $\mathrm{PBIAS} \geq \pm 25$ & $\mathrm{RSR}>0.70$ & Unsatisfactory & Unsatisfactory \\
\hline
\end{tabular}


Hydrol. Earth Syst. Sci. Discuss., https://doi.org/10.5194/hess-2017-424

Manuscript under review for journal Hydrol. Earth Syst. Sci.

Discussion started: 11 August 2017

Table 5. Correlation coefficient for observed-simulated streamflows.

\begin{tabular}{|c|c|c|c|c|c|c|c|}
\hline Catchment & ABCD & AWBM & GR2M & GUO-5P & Témez & $\begin{array}{l}\text { THOR- } \\
\text { MATH }\end{array}$ & Average \\
\hline PUE & 0.79 & 0.84 & 0.91 & 0.83 & 0.84 & 0.77 & 0.86 \\
\hline BEG & 0.92 & 0.92 & 0.93 & 0.91 & 0.92 & 0.92 & 0.91 \\
\hline LEM & 0.89 & 0.89 & 0.93 & 0.88 & 0.90 & 0.88 & 0.90 \\
\hline PRI & 0.87 & 0.88 & 0.89 & 0.88 & 0.89 & 0.93 & 0.90 \\
\hline GAR & 0.88 & 0.90 & 0.90 & 0.92 & 0.92 & 0.90 & 0.78 \\
\hline HOY & 0.66 & 0.66 & 0.67 & 0.67 & 0.66 & 0.58 & 0.73 \\
\hline SEG & 0.83 & 0.83 & 0.84 & 0.84 & 0.72 & 0.84 & 0.77 \\
\hline TAM & 0.89 & 0.89 & 0.90 & 0.89 & 0.89 & 0.59 & 0.85 \\
\hline CUE & 0.71 & 0.87 & 0.90 & 0.89 & 0.89 & 0.87 & 0.77 \\
\hline RVA & 0.61 & 0.75 & 0.85 & 0.80 & 0.59 & 0.52 & 0.69 \\
\hline $\begin{array}{c}\text { Best fit } \\
\text { (Number of times) }\end{array}$ & $\mathbf{0}$ & $\mathbf{0}$ & 13 & 1 & 1 & 1 & \\
\hline
\end{tabular}

5 Table 6. Bressiani classification values. Best results in bold

\begin{tabular}{ccccccccc}
\hline Catchment & ABCD & AWBM & GR2M & $\begin{array}{c}\text { GUO- } \\
\mathbf{5 P}\end{array}$ & Témez & $\begin{array}{c}\text { THOR- } \\
\text { MATH }\end{array}$ & Average & $\begin{array}{c}\text { Ensemble } \\
\text { Classification }\end{array}$ \\
\hline PUE & 3 & 0 & $\mathbf{8}$ & 7 & 0 & 5 & 3.83 & S \\
\hline AND & $\mathbf{9}$ & 7 & $\mathbf{9}$ & $\mathbf{9}$ & 7 & 8 & 8.17 & $\mathbf{V}$ \\
\hline BEG & $\mathbf{9}$ & 8 & $\mathbf{9}$ & $\mathbf{9}$ & 8 & 8 & 8.50 & $\mathbf{V}$ \\
\hline LEM & 4 & 7 & 0 & 3 & $\mathbf{9}$ & 7 & 5.00 & $\mathbf{G}$ \\
\hline TRE & $\mathbf{9}$ & 7 & $\mathbf{9}$ & 8 & $\mathbf{9}$ & 8 & 8.33 & $\mathbf{V}$ \\
\hline COT & 4 & 0 & 5 & 7 & 0 & $\mathbf{9}$ & 4.17 & $\mathbf{S}$ \\
\hline PRI & 7 & 7 & $\mathbf{9}$ & 7 & 8 & 7 & 7.50 & $\mathbf{G}$ \\
\hline GAR & 0 & $\mathbf{9}$ & 7 & $\mathbf{9}$ & 0 & $\mathbf{9}$ & 5.67 & $\mathbf{G}$ \\
\hline HOY & 4 & 0 & 0 & 0 & 0 & $\mathbf{5}$ & 1.50 & $\mathbf{U}$ \\
\hline SEG & $\mathbf{9}$ & 5 & 3 & 4 & 3 & 8 & 5.33 & $\mathbf{G}$ \\
\hline ZUM & $\mathbf{7}$ & 5 & $\mathbf{7}$ & 5 & 0 & 5 & 4.83 & $\mathbf{G}$ \\
\hline JUB & 5 & 3 & 4 & 3 & 0 & $\mathbf{7}$ & 3.67 & $\mathbf{S}$ \\
\hline BOL & 3 & 0 & 0 & 0 & $\mathbf{4}$ & 3 & 1.67 & $\mathbf{U}$ \\
\hline TAM & 0 & 0 & 0 & $\mathbf{3}$ & 0 & 0 & 0.50 & $\mathbf{U}$ \\
\hline CUE & 0 & 0 & 0 & 0 & 0 & 0 & 0.00 & U \\
\hline
\end{tabular}


Hydrol. Earth Syst. Sci. Discuss., https://doi.org/10.5194/hess-2017-424

Manuscript under review for journal Hydrol. Earth Syst. Sci.

\begin{tabular}{ccccccccc}
\hline RVA & 0 & 0 & 0 & 0 & 0 & 0 & 0.00 & U \\
\hline Average & $\mathbf{4 . 5 6}$ & $\mathbf{3 . 6 3}$ & $\mathbf{4 . 3 8}$ & $\mathbf{4 . 6 3}$ & $\mathbf{3 . 0 0}$ & $\mathbf{4 . 5 6}$ & & \\
\hline C.V. (\%) & $\mathbf{7 8 . 0 1}$ & $\mathbf{9 7 . 7 4}$ & $\mathbf{8 9 . 7 3}$ & $\mathbf{7 6 . 1 7}$ & $\mathbf{1 2 9 . 2 2}$ & $\mathbf{7 8 . 0 1}$ & & \\
\hline $\begin{array}{c}\text { Best fit } \\
\text { (Number of } \\
\text { times) }\end{array}$ & 5 & 1 & 6 & 3 & 4 & 4 & & \\
\hline
\end{tabular}

Table 7. REV (\%) values. Best results in bold.

\begin{tabular}{ccccccc}
\hline Catchment & ABCD & AWBM & GR2M & $\begin{array}{c}\text { GUO- } \\
\text { 5P }\end{array}$ & Témez & $\begin{array}{c}\text { THOR- } \\
\text { MATH }\end{array}$ \\
\hline PUE & -2.95 & -29.46 & 2.67 & -2.57 & -29.98 & $\mathbf{0 . 6 0}$ \\
\hline AND & -10.09 & -15.46 & $\mathbf{1 . 0 5}$ & -3.68 & -15.78 & -13.86 \\
\hline BEG & -5.02 & -10.06 & 21.61 & $\mathbf{0 . 6 6}$ & -8.70 & -9.81 \\
\hline LEM & 16.24 & $\mathbf{- 4 . 4 9}$ & -16.22 & -23.47 & 4.62 & 23.55 \\
\hline TRE & 8.20 & -7.55 & 37.68 & 14.06 & $\mathbf{0 . 7 4}$ & -2.86 \\
\hline COT & $\mathbf{- 1 . 2 0}$ & -41.41 & 2.19 & -4.34 & -36.84 & 3.43 \\
\hline PRI & $\mathbf{- 0 . 8 0}$ & -8.24 & 15.48 & 11.59 & -10.28 & -5.27 \\
\hline GAR & 63.44 & 45.58 & 22.27 & $\mathbf{3 . 4 3}$ & 54.02 & 52.81 \\
\hline HOY & 11.20 & -35.00 & 31.60 & 17.78 & -32.90 & $\mathbf{- 1 . 7 5}$ \\
\hline SEG & 20.24 & 5.59 & $\mathbf{- 0 . 7 5}$ & -4.07 & 5.43 & 11.21 \\
\hline ZUM & 16.25 & $\mathbf{- 3 . 8 7}$ & 16.81 & 6.72 & 26.54 & 7.25 \\
\hline JUB & -18.60 & $\mathbf{- 1 7 . 9 2}$ & 88.28 & 52.69 & -26.40 & -21.58 \\
\hline BOL & 37.20 & 19.25 & -30.62 & $\mathbf{1 2 . 3 9}$ & 27.70 & 20.38 \\
\hline TAM & 113.54 & 64.59 & -37.41 & $\mathbf{- 3 . 6 1}$ & 97.40 & -18.45 \\
\hline CUE & 32.61 & 27.92 & 48.22 & $\mathbf{1 3 . 6 1}$ & 38.61 & 47.20 \\
\hline RVA & -26.95 & -34.30 & 24.74 & $\mathbf{1 . 0 4}$ & -77.66 & -78.97 \\
\hline $\begin{array}{c}\text { Average (absolute } \\
\text { value) }\end{array}$ & $\mathbf{2 4 . 0 3}$ & $\mathbf{2 3 . 1 7}$ & $\mathbf{2 4 . 8 5}$ & $\mathbf{1 0 . 9 8}$ & $\mathbf{3 0 . 8 5}$ & $\mathbf{1 9 . 9 4}$ \\
\hline $\begin{array}{c}\text { Best fit } \\
\text { (Number of times) }\end{array}$ & $\mathbf{2}$ & $\mathbf{3}$ & $\mathbf{2}$ & $\mathbf{6}$ & $\mathbf{1}$ & $\mathbf{2}$ \\
\hline & & & & & &
\end{tabular}


Hydrol. Earth Syst. Sci. Discuss., https://doi.org/10.5194/hess-2017-424

Manuscript under review for journal Hydrol. Earth Syst. Sci.

Discussion started: 11 August 2017

Table 8. Summary of performance of the selected water models.

\begin{tabular}{cccccccc}
\hline Catchment & $\begin{array}{c}\text { Area } \\
\left(\mathbf{k m}^{\mathbf{2}}\right)\end{array}$ & $\begin{array}{c}\text { Altitude } \\
\mathbf{( M A S L )}\end{array}$ & $\begin{array}{c}\text { Water } \\
\text { Model }\end{array}$ & $\mathbf{R}$ & $\begin{array}{c}\text { Bressiani } \\
\text { Sum }\end{array}$ & $\begin{array}{c}\text { Bressiani } \\
\text { Classification }\end{array}$ & $\begin{array}{c}\text { REV } \\
(\mathbf{\%})\end{array}$ \\
\hline PUE & 263.85 & 400.05 & GR2M & 0.91 & 8 & Very Good & +2.67 \\
\hline AND & 778.49 & 486.01 & GR2M & 0.91 & 9 & Very Good & +1.05 \\
\hline BEG & 836.89 & 504.01 & Guo5p & 0.91 & 9 & Very Good & +0.66 \\
\hline LEM & 252.58 & 342.18 & Témez & 0.90 & 9 & Very Good & +4.62 \\
\hline TRE & 413.54 & 526.64 & Témez & 0.89 & 9 & Very Good & +0.74 \\
\hline COT & 488.22 & 559.51 & Thor- & & & Very Good & +3.43 \\
\hline PRI & 328.16 & 1255.05 & Témez & 0.89 & 8 & Very Good & -10.28 \\
\hline GAR & 69.92 & 689.98 & Guo5p & 0.92 & 9 & Very Good & +3.43 \\
\hline HOY & 66.15 & 1632.12 & Thor- & & & Good & -1.75 \\
\hline SEG & 232.89 & 1416.46 & Thor- & & & Very Good & +11.21 \\
\hline ZUM & 266.03 & 1549.95 & GR2M & 0.82 & 7 & Very Good & +16.81 \\
\hline JUB & 207.66 & 1150.05 & Thor- & & & Very Good & -21.58 \\
\hline BOL & 29.23 & 600.31 & Témez & 0.73 & 4 & Satisfactory & +27.70 \\
\hline TAM & 458.12 & 447.46 & Guo5p & 0.89 & 3 & Satisfactory & -3.61 \\
\hline CUE & 139.86 & 610.63 & Guo5p & 0.89 & 0 & Unsatisfactory & +13.61 \\
\hline RVA & 85.68 & 607.70 & Guo5p & 0.80 & 0 & Unsatisfactory & +1.04 \\
\hline
\end{tabular}

